\title{
Hydro-climatic and land use/cover changes in Nasia catchment of the White Volta basin in Ghana
}

\author{
Emmanuel Nyadzi ${ }^{1}$ (I) Enoch Bessah ${ }^{2} \cdot$ Gordana Kranjac-Berisavljevic $^{3} \cdot$ Fulco Ludwig $^{1}$
}

Received: 14 May 2021 / Accepted: 4 September 2021 / Published online: 1 October 2021

(c) The Author(s) 2021

\begin{abstract}
The Nasia catchment is the reservoir with significant surface water resources in Northern Ghana and home to numerous subsistence farmers engaged in rainfed and dry season irrigation farming. Yet, there is little understanding of the hydro-climatic and land use/cover conditions of this basin. This study investigated trends, relationships and changes in hydro-climatic variables and land use/cover in addition to implications of the observable changes in the Nasia catchment over a period of 50 years. Parameters used for the study were minimum (Tmin) and maximum temperature (Tmax), wind speed (WS), sunshine duration (S), rainfall (R), relative humidity (RH), discharge (D) and potential evapotranspiration (PET) data, 15 years of remotely sensed normalized difference vegetation index (NDVI) data and 30 years of land use/cover image data. Results show that Tmin, Tmax, WS and PET have increased significantly $(p<0.05)$ over time. RH and S significantly declined. R, $\mathrm{D}$ and NDVI have not decreased significantly $(p>0.05)$. A significant abrupt change in almost all hydro-climatic variables started in the 1980s, a period that coincides with the occurrence of drought events in the region, except WS in 2001, R in 1968 and D in 1975, respectively. Also, D showed a positive significant correlation with RH, R and PET, but an insignificant positive relationship with S. D also showed a negative insignificant correlation with Tmin, Tmax and WS. Areas covered with shrubland and settlement/bare lands have increased to the disadvantage of cropland, forest, grassland and water bodies. It was concluded that climate change impact is quite noticeable in the basin, indicating water scarcity and possibilities of droughts. The analysis performed herein is a vital foundation for further studies to simulate and predict the effect of climate change on the water resources, agriculture and livelihoods in the Nasia catchment.
\end{abstract}

\section{Introduction}

Climate change presents the most pressing challenge of the twenty-first century, with extraordinary impact on natural ecosystems, economic sectors, society and water resources (Arnell 2004; Khaliq et al. 2009; Sabbaghi et al. 2020; de Hipt et al. 2018; Schilling et al. 2020; Baarsch et al. 2020). Climate change is unequivocal, manifested by rapid warming

Emmanuel Nyadzi

emmanuel.nyadzi@wur.nl; enyadzi@yahoo.com

1 Water Systems and Global Change Group, Wageningen University, P.O. Box 47, 6700 AA Wageningen, The Netherlands

2 Department of Agricultural and Biosystems Engineering, Kwame Nkrumah University of Science and Technology, Kumasi, Ghana

3 Department of Agricultural Mechanisation and Irrigation Technology, University for Development Studies, Tamale, Ghana of the globe and increasing the frequency of extreme events, such as floods and droughts (IPCC 2014). Africa, for example, is expected to experience negative climate change impacts, contributing to already present problems of widespread poverty and low development (World Bank 2010; Mikulewicz and Taylor 2020). At the background of climate change is the variability of the hydro-climatic parameters, such as temperature, rainfall, relative humidity, discharge, potential evapotranspiration and radiation, both in their long-term average and by an increase over time. The already high temperatures and largely erratic rainfall are expected to increase in sub-Saharan Africa over the twenty-first century (Speranza 2010; IPCC 2014; Serdeczny et al. 2017; Codjoe and Atiglo 2020).

Variations in climatic conditions are important determinants of vegetation growth and density across the world and, especially, in tropical and subtropical Africa (Warburton et al. 2012; Schmidt et al. 2014). Also, feedbacks from land surface processes and vegetation dynamics influence local and regional climate variability 
(Wang and Eltahir 2000), especially in West Africa and the Sahel Zone (Long et al. 2000; Nicholson et al. 2000; Los et al. 2006; Paeth et al. 2009). Changes in land cover, particularly vegetation, are likely to aggravate the climate change situation in a way that the hydrological cycle will be altered, resulting in an increase in frequency and severity of droughts and floods which in turn influences agriculture, water supply, environmental sustainability and protection from floods (Aduah et al. 2018). The combined effects of climate variability, land use/cover changes and unsustainable water management practices have led to a significant alteration in the water balance of the river basins (Buma et al. 2016). Land use/cover changes are caused by population pressure as well as expansion of agricultural lands through unplanned and inappropriate land management practices to meet the food demands of a rapidly growing population. Unsustainable land use/cover activities, therefore, affect soil structure, texture and fertility that play a key role in food production (Lal et al. 2015).

Analysing the direction and magnitude of the variation in the hydro-climatic variables is important for understanding climate change and providing a basis for determining future scenarios of climate impact (Chaouche et al. 2010; Reiter et al. 2012; Unal et al. 2012; Asfaw et al. 2018; Meshram et al. 2020). Detecting the historical trend of vegetation, often expressed in normalized difference vegetation index (NDVI) and land use/cover changes, particularly improves our understanding of the changing planet and provides a clue about the productivity of lands (Tian et al. 2015; Gichenje and Godinho 2018; Frédérique et al. 2019; Rezende et al. 2020). Trend analysis of hydro-climatic variables and vegetation is particularly relevant for water resource decisionmakers as they prepare to deal with the possible effects of climate variability and change on water availability (Sahoo and Smith 2009; Oguntunde et al. 2006; Zhou et al., 2015a, b; Tehrani et al. 2019).

Many regions of the world are increasingly facing a decline in freshwater resources, due to both natural and manmade causes. Climate and land use/cover change are likely to aggravate this situation in a way that the hydrological cycle will be intensified resulting in an increase in frequency and severity of droughts and floods which influences agriculture, water supply, environmental sustainability and protection from floods and infrastructure (Aduah et al. 2018). Depending on the severity, water deficits can result in catastrophic consequences (Amisigo, 2006).

The availability of freshwater in sub-Saharan Africa is fundamental to economic growth and social development (Kankam-Yeboah et al., 2013). In the Volta basin of West Africa, where Ghana is situated, there are competing demands for water use both within and among the riparian countries of the basin. This is manifested in the numerous dams and reservoirs constructed throughout the basin for various purposes including industrial, agricultural and domestic water supplies (Amisigo, 2006).

The Ghana Water Research Institute of the Council for Scientific and Industrial Research (CSIR-WRI) reports that all river basins in Ghana will be vulnerable and the whole country will face acute water shortage by the year 2020 (Kankam-Yeboah et al., 2011). It also reported a general reduction in annual river flows in Ghana by $15-20 \%$ for the year 2020 and $30-40 \%$ for the year 2050 , due to an increased irrigation water demand of $40-150 \%$ for 2020 and $150-1200 \%$ for 2050 (Kankam-Yeboah et al., 2011). According to Abdul-Ganiyu et al. (2011), the main surface water resources in Northern Ghana are concentrated in the White Volta and the Nasia River systems, which flows only 3 or 4 months during the year, causing seasonal deficits across the region. This poses serious problems for traditional rainfed agriculture, especially as food demand grows, thus slowing down rural development. Also, the authors mention that the seasonal shortage of water affects irrigation during the dry season for the Nasia Irrigation Project, which operates as a run-of-river scheme for all year-round crop production. The predominant land use is arable food production and widespread grazing of large numbers of cattle and other livestock. Plinthic ferralsols (groundwater laterites) and Eutric nitosols (savannah ochrosols) with their intergrades are the predominant soil types in this region (Addai et al., 2016).

Given the above situation and pressing issues, understanding the hydro-climatic variability and land use/cover changes in the Nasia River catchment is important in Northern Ghana, because the availability of water resources is a significant factor in this highly productive agricultural region. While the causes and the mechanisms of these changes are a matter for other studies, the relevant question for this case is how has climate change affected the trends of these hydro-climatic variables? Therefore, the objective of this study was to determine the historical trends in selected hydro-climatic variables (minimum and maximum temperature, wind speed, sunshine duration, rainfall, relative humidity, discharge and potential evapotranspiration), NDVI and land use cover/change in Nasia sub-basin of the White Volta and to establish the relationship between these parameters and discuss the possible implications of the observable changes in the Nasia catchment to agriculture in the region.

\section{Methodology}

\subsection{The Nasia River catchment}

The Nasia River (Fig. 1) is a tributary of the White Volta in the Northern Region of Ghana, with a catchment area of about $5,400 \mathrm{~km}^{2}$ and a mean annual runoff of 550 million $\mathrm{m}^{3}$ (WRCG 2008). It is geographically positioned 


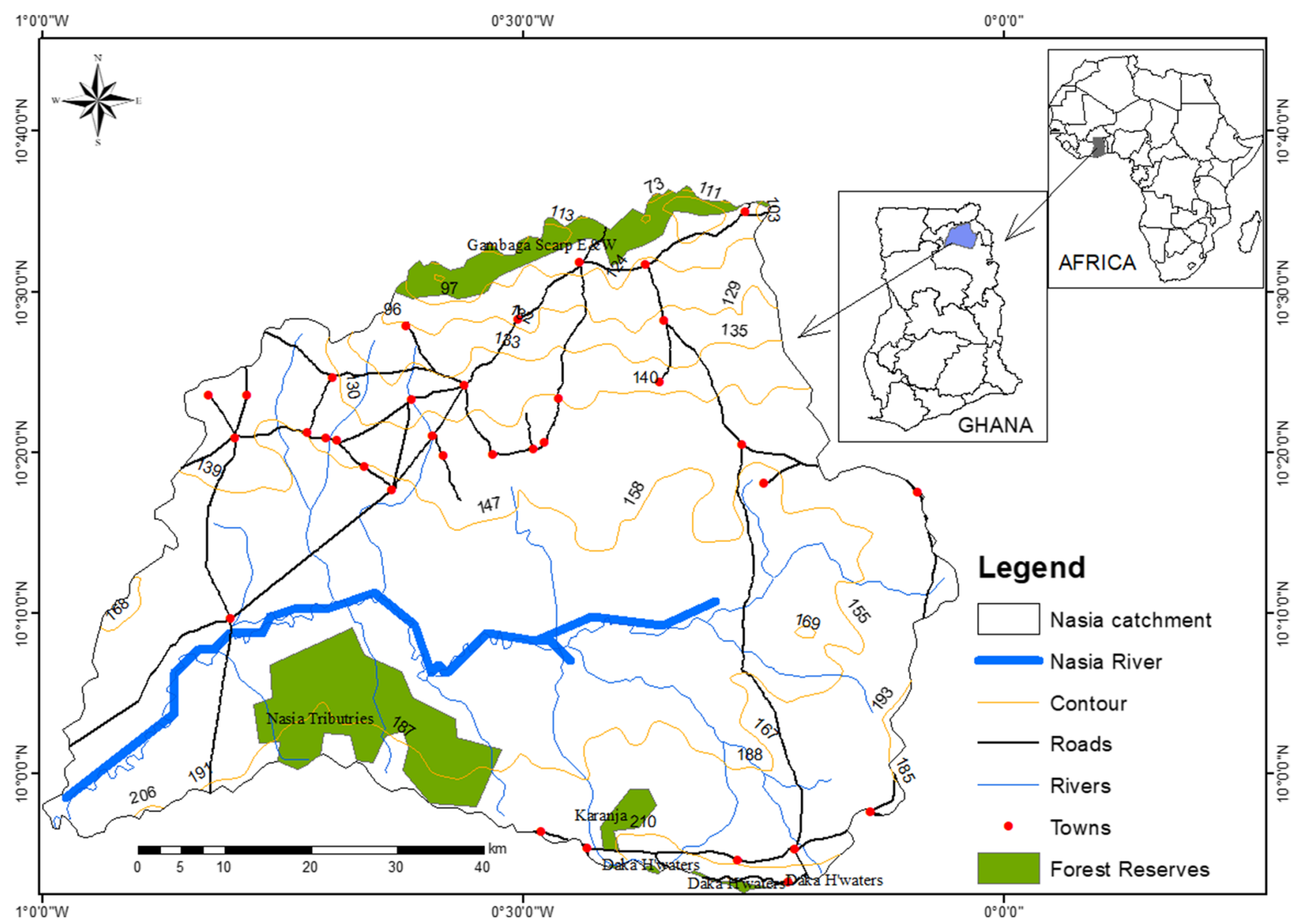

Fig. 1 Map of Nasia catchment (Authors' design, 2020)

between latitudes $9^{\circ} 55^{\prime}$ and $10^{\circ} 40^{\prime} \mathrm{N}$ and longitudes $1^{\circ}$ $05^{\prime} \mathrm{W}$ and $0^{\circ} 15^{\prime} \mathrm{E}$ (Adu, 1995). The area is characterized by unimodal rainfall, with an annual average between 1000 and $1300 \mathrm{~mm}$, which peaks between late August and early September (Elikplim et al., 2018). Temperatures in this region are consistently high. The hottest months in the year are March and April, just before the beginning of the rainy season, while the coolest months are July and August. The average maximum and minimum temperatures of $34^{\circ} \mathrm{C}$ and $23{ }^{\circ} \mathrm{C}$, respectively, are recorded in the basin (Abdul-Ganiyu et al. 2011). The floodplain soils vary in texture, from very fine sands to heavy clays, and are developed over levees, old river beds, sloughs and low river terraces. Most of the Nasia catchment is very gently undulating. It has broad, poorly drained valleys and extensive floodplains adjacent to the Volta and Nasia rivers, where altitudes vary between 108 and $138 \mathrm{~m}$ above mean sea level (Abdul-Ganiyu et al. 2011). It has a relatively short rainy period, stretching from May to October, with estimated reference evapotranspiration (ETo) above $1600 \mathrm{~mm} /$ annum (Kranjac-Berisavljevic, 1999). The remaining months of the year are very dry, posing challenges to domestic and agricultural activities, due to water unavailability in the basin. The people of the area are engaged in subsistence agriculture mainly on "compound farms" which lie immediately around the houses and "bush farms", which may border on the compound farm or are located several kilometres away from the main communities. Rice, maize, legumes and vegetables are cultivated in the rainy season, while tomatoes and onions are cultivated in the dry season under irrigation. Many householders rear sheep and goats, as well as chickens and guinea fowls, but few others keep cattle. The animals are kept for security reasons or as a capital investment (Abdul-Ganiyu et al. 2011).

\subsection{Data collection and quality assurance}

This study utilized climate, hydrological and land use/ cover (LULC) data (Table 1). Fifty years of daily hydroclimatological data were collected from relevant government institutions. The hydrological data, i.e. river discharge, was obtained from the Ghana Hydrological Services Department (HSD), while the climatic data, i.e. rainfall, minimum 
Table 1 Summary of data types, timesteps and sources

\begin{tabular}{lll}
\hline Parameter & Period & Source of data \\
\hline Rainfall & $1961-2010$ & GMET \\
Minimum temperature & $1961-2010$ & GMET \\
Maximum temperature & $1961-2010$ & GMET \\
Wind speed & $1961-2010$ & GMET \\
Sunshine & $1961-2010$ & GMET \\
Relative humidity & $1961-2010$ & GMET \\
Discharge & $1961-2010$ & HSD \\
NDVI & $2002-2017$ & NASA Giovanni \\
LULC map 1 & 2000 & GlobeLand30 \\
LULC map 2 & 2010 & GlobeLand30 \\
LULC map 3 & 2020 & GLOVIS (Landsat 8 image) \\
\hline
\end{tabular}

Missing values of the data were handled with the "na_interpolation" function in an $\mathrm{R}$ package called imputeS. The package estimates missing value by interpolation (Moritz and Bartz-Beielstein 2017).

temperature and maximum temperature, relative humidity, wind speed and sunshine, were collected from Ghana Meteorological Agency (GMET) for the Tamale synoptic station. Also, annual NDVI data was collected from NASA Giovanni website. Derived from red and near-infrared band reflectance, NDVI is an efficient indicator for vegetation monitoring due to its simplicity and close relation to vegetation productivity (Tian et al. 2015). NDVI provides information about the quantity of vegetation present in a given area and its state of health or vigour of growth thus a good indicator for degradation (Meneses-Tovar 2011). More than 20 vegetation indices have been proposed and used at present, yet NDVI has been widely used with its values ranging from -1.0 to 1.0 , where higher values are for green vegetation and low values for other common surface materials such as bare soil represented with NDVI values close to 0 and water bodies having negative NDVI values (Jasinski 1990; Sader and Winne 1992; Lillesand et al. 2004; Sesnie et al. 2008).

LULC maps of 2000 and 2010 were obtained from the GlobeLand30 map generated by the Chinese Government and the 2020 LULC map generated from Landsat 8 image acquired from the US Geological Survey GLOVIS website.

\subsection{Data analysis}

\subsubsection{Analysis of hydroclimate and NDVI variables}

The hydro-climatic and NDVI data were analysed using the R statistical software. The datasets were first separately analysed to determine trends and subsequently together to describe the relationship between the variables. The analysis generally followed three main steps. First, analysis of basic statistical properties of the variables was determined using the mean, median, mode, skewness and kurtosis, variance and standard deviation.

Secondly, the Mann-Kendall trend test (Mann 1945), a non-parametric method, was used to investigate the trends in annual rainfall $(\mathrm{mm})$, annual discharge $\left(\mathrm{m}^{3} \mathrm{~s}^{-1}\right)$, relative humidity $(\%)$ and minimum and maximum temperature $\left({ }^{\circ} \mathrm{C}\right)$, wind speed (km/day), sunshine (h) and NDVI data. The presence of a breakpoint in the time series of annual averages of the variables was examined using the non-parametric test of Pettitt (Pettitt, 1979). Pettitt's test allows the detection of abrupt changes, whether artificial or natural, in the mean of the time series (Mallakpour and Villarini 2016).

The null hypothesis was tested at a 95\% confidence level $(\alpha=0.05)$ for all the variables. The Mann-Kendall trend test was selected because it accommodates missing data and outliers and does not require the data to be normally distributed (Partal and Kahya, 2006). At the same time, it has low sensitivity to abrupt breaks due to inhomogeneous time series (Tabari and Talaee 2011). This test has been extensively and successfully used to detect trends in hydro-climatic studies (Xu et al. 2010; Sun et al. 2013; Zhang et al. 2015; Mwangi et al. 2016) and NDVI (Forkel et al. 2013; Osunmadewa et al. 2014).

The null hypothesis $\mathrm{H} 0$ assumes that there is no significant trend (the data is independent and randomly ordered) and this is tested against the alternative hypothesis $\mathrm{H} 1$, which assumes that there is a significant trend (Önöz and Bayazit 2012). The test statistic Zs is used as a measure of the significance of the trend. This test statistic is used to test the null hypothesis, H0. Kendall's tau was used to measure the strength of the trend. In addition to the Mann-Kendall test, the results in linear trend lines were compared and plotted for each variable. The Mann-Kendall test statistic (S) is given as follows (Gocic and Trajkovic 2013; Kambombe 2018):

$S=\left\{\begin{array}{cl}(S-1 / \sqrt{\operatorname{Var}(S)} & \text { if } \mathrm{S}>0 \\ 0 & \text { if } \mathrm{S}=0 \\ (s+1 / \sqrt{\operatorname{Var}(S)} & \text { if } \mathrm{S}<0\end{array}\right.$

where

$\operatorname{sgn}\left(x_{j}-x_{k)}=\left\{\begin{array}{cl}1 & \text { if }\left(x_{j}-x_{k}\right)>0 \\ 0 & \text { if }\left(x_{j}-x_{k}\right)=0 \\ -1 & \text { if }\left(x_{j}-x_{k}\right)<0\end{array}\right.\right.$

When $S$ is greater than 0 , it implies a positive trend, and a negative $S$ indicates a decreasing trend. The $S$ is approximately normally distributed for $n \geq 8$, with the variance given as: 
$\operatorname{Var}(S)=\frac{1}{18}[n(n-1)(2 n+5)]$

In case of tied ranks in the data, the statistic $\mathrm{Zs}=0$ and variance of $\mathrm{S}, \operatorname{Var}(S)$ is calculated by:

$\operatorname{Var}(S)=\frac{1}{18}\left[n(n-1)(2 n+5)-\sum_{p-1}^{q} t_{p}\left(t_{p}-1\right)\left(2 t_{p}+5\right)\right]$

where $q$ is the number of tied groups and $t_{p}$ is the number of data values in the $P^{t h}$ group. The standardized $Z$ value is used to determine the significance of any trend in the data set. The null hypothesis stating that there is no trend in the dataset is rejected $\left|Z_{c}\right|$ or $>Z_{1-\alpha / 2}$ or if the $p$-value is less than the level of significance $(p<\alpha=0.05)$. Sen's slope technique estimates the magnitude of monotonic trends in $N$ pairs of data which was used in this study (Hirsch et al. 1982). A monotonic upward or downward trend for a variable implies that there is a consistent increase or decrease in the variable through time, but the trend may or may not be linear (Hirsch et al. 1982). Sen's slope is given as:

$\mathcal{Q}_{i}=\frac{x_{j}-x_{k}}{j-k}$ fori $=, \ldots, N$,

in which $Q i$ is Sen's slope while $x_{j}$ and $x_{k}$ are data values in years $\mathrm{j}$ and $\mathrm{i}$, where $1<\mathrm{j}<\mathrm{i}<n$. A positive $\mathcal{Q}_{i}$ value indicates an upward trend, while a negative value indicates a downward trend.

Thirdly, Pearson's correlation analysis was used to determine the relationship between the variables.

\subsubsection{Image processing and land use land cover mapping}

The LULC maps of 2000 and 2010 were extracted from the GlobeLand30 maps produced by the Chinese Government (global land cover map at a spatial resolution of $30 \mathrm{~m}$ ) (Jun et al. 2014). Two scenes of the GlobeLand30 dataset covering Ghana, that is, N30_05 and N30_10, were mosaicked since the basin fell within both scenes. The 2020 map classification was performed by the authors. The classes in the 2000 and 2010 maps were adopted for the 2020 classification, i.e. cropland, forest, grassland, shrubland, water bodies and settlement/bare areas. Bare areas were combined with settlement due to the dryness of the basin located in the Guinea Savannah zones. Moreover, most of the settlements are farming communities with less reflective roofs (thatch roofs) to depict settlement.

Landsat 8 images at $30 \mathrm{~m}$ spatial resolution and cloud cover criterion of less than $10 \%$ acquired on 26 February 2020 from path 194 row 53 were acquired freely from the United States Geological Survey's (USGS) GLOVIS. Atmospheric correction for temporal analysis was done in QGIS under the Semi-Automatic Classification Plugin (SCP). The random forest algorithm machine learning was used to classify the image in R software (Thanh Noi and Kappas 2018). The 2016 European Space Agency (ESA) Climate Change Initiative (CCI) S2 prototype land cover map at $20 \mathrm{~m}$ of Africa was acquired from ESA and combined with Google Earth image of 2020, and observation or knowledge of the basin were references used for the classification (Forkuo and Frimpong, 2012). Both pixel-based and areabased error matrix was done to assess the accuracy of the classification (Olofsson et al., 2013).

The overall accuracy of the 2000 and 2010 GlobeLand 30 is $78.6 \%$ and $80.33 \%$ respectively, which was validated by over 150,000 points in 80 out of 853 tiles for the 2010 land cover map (Chen et al. 2015). The overall accuracy for the 2020 LULC maps was $90.53 \%$ and $77.15 \%$ for the pixelbased and area-based error matrix assessment respectively (see Tables 5 and 6 in Appendix for details of the pixelbased and area-based error matrix for 2020).

\section{Results}

In this section, the findings of the analysis are presented in three main ways. Firstly, the descriptive statistics of the 8 variables (climate, hydrological and NDVI data) are shown. Secondly, the results of the trends in the variables are also presented. Thirdly, the relationship between these variables and how they influence river discharge was established using a multivariate regression model.

\subsection{Temporal characteristics of the variables in Nasia catchment}

Over 50 years (1961-2010), the Nasia catchment received an annual total rainfall (R) ranging from 695 to $1666 \mathrm{~mm}$, with a mean value of $1093 \mathrm{~mm}$. Discharge (D) of the Nasia River ranged from as low as 7.83 to $20,757.3 \mathrm{~m}^{3} / \mathrm{s}$ with a mean flow of $6931.6 \mathrm{~m}^{3} / \mathrm{s}$. Also, within the 50 years, the catchment recorded an average minimum (Tmin) and maximum (Tmax) temperature of $22.6{ }^{\circ} \mathrm{C}$ and $34.1{ }^{\circ} \mathrm{C}$ respectively, the average sunshine (Sun) in hours per day of 7.3, with relative humidity (RH) of $57.98 \%$. The average wind speed (WS) over 50 years is $3.25 \mathrm{kt}$. Also, the average NDVI for the 16 years is 0.47 . Table 2 provides descriptive statistics of the selected variables.

\subsection{Annual trends in the selected variables}

The observed slope for D, R, S, RH and NDVI was negative, indicating a decreasing trend, while Tmin, Tmax, WS and PET showed an increasing trend. The decreasing trend in $\mathrm{R}$ and D was insignificant $(p>0.05)$ at a rate of $-0.086 \mathrm{~mm} /$ 
Table 2 Summary statistics of selected hydro, climate and vegetation variables in Nasia catchment

\begin{tabular}{|c|c|c|c|c|c|c|c|c|c|}
\hline Statistic & $\operatorname{Tmin}\left({ }^{\circ} \mathrm{C}\right)$ & $\operatorname{Tmax}\left({ }^{\circ} \mathrm{C}\right)$ & WS (kt) & S (Hrs/day) & $\mathrm{R}$ (mm/year) & $\mathrm{RH}(\%)$ & $\mathrm{D}\left(\mathrm{m}^{3} / \mathrm{s}\right)$ & PET $(\mathrm{mm})$ & NDVI \\
\hline No. of observations & 50 & 50 & 50 & 50 & 50 & 50 & 50 & 50 & 16 \\
\hline Minimum & 21.7 & 33.01 & 2.47 & 5.7 & 695.30 & 25.45 & 7.83 & 1111.10 & 0.43 \\
\hline Maximum & 23.5 & 36.20 & 4.19 & 8.6 & 1579.80 & 65.67 & $20,757.3$ & 2329.30 & 0.57 \\
\hline 1st quartile & 22.2 & 33.64 & 2.86 & 7.1 & 996.63 & 57.28 & 2785.5 & 1994.50 & 0.46 \\
\hline Median & 22.6 & 34.11 & 3.16 & 7.4 & 1076.05 & 59.67 & 6869.5 & 2092.61 & 0.47 \\
\hline 3rd quartile & 22.9 & 34.44 & 3.49 & 7.6 & 1162.30 & 61.39 & $10,301.5$ & 2187.93 & 0.48 \\
\hline Mean & 22.6 & 34.10 & 3.25 & 7.3 & 1093.99 & 57.98 & 6931.6 & 2009.51 & 0.47 \\
\hline Standard deviation $(n)$ & 0.44 & 0.59 & 0.47 & 0.43 & 181.81 & 6.87 & 5312.2 & 317.43 & 0.03 \\
\hline Variation coefficient $(n)$ & 0.02 & 0.02 & 0.14 & 0.06 & 0.17 & 0.12 & 0.8 & 0.16 & 0.06 \\
\hline Skewness (Pearson) & 0.13 & 0.67 & 0.32 & -0.92 & 0.43 & -2.76 & 0.5 & -2.05 & 2.31 \\
\hline Kurtosis (Pearson) & -1.04 & 1.33 & -0.80 & 3.48 & 0.41 & 8.99 & -0.3 & 3.22 & 6.14 \\
\hline
\end{tabular}

(Authors' computations, 2020).

year and $-35.485 \mathrm{~m}^{3} /$ year, respectively. S, RH and NDVI were, however, significant $(p<0.05)$ at a rate of $-0.007 \mathrm{~h} /$ day/year, $-0.084 \%$ and -0.002 , respectively. A significant $(p<0.05)$ increasing trend was observed for the remaining variables $\left(\operatorname{Tmin}\left(0.022^{\circ} \mathrm{C}\right)\right.$, $T \max \left(0.028^{\circ} \mathrm{C}\right)$ and PET $(4.233 \mathrm{~mm})$ ) except for WS which increased at an insignificant rate of $0.008 \mathrm{kt}$.

$\mathrm{R}$ recorded an earlier but insignificant change in mean value in the year 1968, which was consistently followed by an insignificant change in D in 1975. Tmax and S observed abrupt changes in the years 1980 and 1981, respectively. Also, a close breakpoint in Tmin and PET was identified in the years 1986 and 1987, respectively. WS and NDVI recorded a breakpoint in the years 2001 and 2014, respectively. Results of the trend and breakpoint year estimates are presented in Table 3. Annual time series, anomalies and correlations for all variables are shown in Figs. 2, 3, and 4 respectively.

\subsection{Relationship of the hydro-climatic variables}

Results show that rainfall contributes significantly to relative humidity and discharge throughout the year, showing a positive relationship. Rainfall also has a positive but insignificant relationship with potential evapotranspiration and sunshine and an insignificant negative correlation with wind speed and minimum and maximum temperatures. Potential evapotranspiration has a significant positive relationship with minimum temperature, relative humidity and discharge but insignificantly increases with maximum temperature, sunshine and rainfall. Potential evapotranspiration also
Table 3 Results of trend and breakpoint detection analysis for the selected variables

\begin{tabular}{|c|c|c|c|c|c|c|c|}
\hline \multirow[t]{2}{*}{ Variables } & \multicolumn{5}{|c|}{ Mann-Kendall's test for trend } & \multicolumn{2}{|c|}{ Pettitt's test for breakpoint } \\
\hline & Kendall's tau & $p$-value & $\begin{array}{l}\text { Kendall } \\
\text { statistic } \\
(\mathrm{S})\end{array}$ & Sen's slope & Trend direction & Breakpoint year & $p$-value \\
\hline Tmin & 0.508 & $<0.0001$ & 622 & 0.022 & Up & 1986 & $<0.0001$ \\
\hline Tmax & 0.537 & $<0.0001$ & 658 & 0.028 & Up & 1980 & $<0.0001$ \\
\hline WS & 0.174 & 0.075 & 213 & 0.008 & Up & 2001 & 0.024 \\
\hline S & -0.232 & 0.018 & -283 & -0.007 & Down & 1981 & 0.009 \\
\hline $\mathrm{R}$ & -0.004 & 0.967 & -5 & -0.086 & Down & 1968 & 0.117 \\
\hline RH & -0.249 & 0.011 & -305 & -0.084 & Down & 1980 & 0.001 \\
\hline $\mathrm{D}$ & -0.048 & 0.622 & -59 & -35.485 & Down & 1975 & 0.154 \\
\hline PET & 0.278 & 0.004 & 341 & 4.233 & Up & 1987 & $<0.0001$ \\
\hline NDVI & -0.417 & 0.026 & -50 & -0.002 & Down & 2014 & 0.226 \\
\hline
\end{tabular}

NB: At $p$-value $>0.0$, the null hypothesis $\left(\mathrm{H}_{0}\right)$ indicating that there is no significant trend in the series or data are homogeneous is rejected. At $p$-value $<0.05$, the alternative hypothesis (Ha) indicating that there is a significant trend in the series or there is a date at which there is a change in the data is accepted (Authors' computations, 2020). 

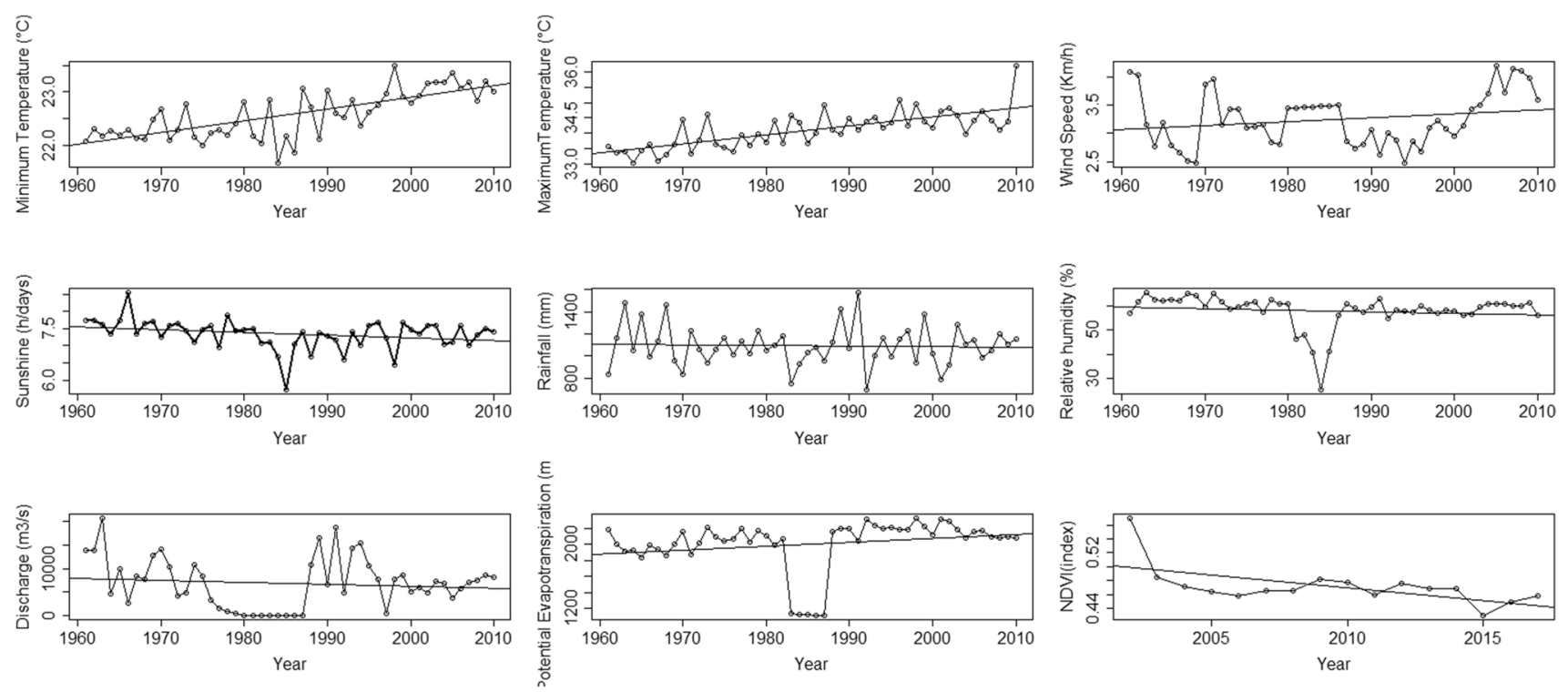

Fig. 2 Time series plots of $\mathrm{D}$, total discharge $\left(\mathrm{m}^{3} / \mathrm{s}\right) ; \mathrm{S}$, sunshine $(\mathrm{h} /$ days); Tmax, maximum temperature $\left({ }^{\circ} \mathrm{C}\right)$; WS, wind speed $(\mathrm{Km} / \mathrm{h})$;

rainfall $(\mathrm{mm})$; PET, potential evapotranspiration $(\mathrm{mm})$; and NDVI, $\mathrm{RH}$, relative humidity (\%); Tmin, minimum temperature $\left({ }^{\circ} \mathrm{C}\right) ; \mathrm{R}$,

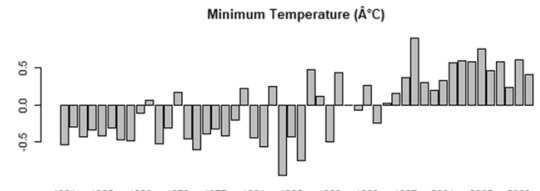

$\begin{array}{lllllllllllll}1961 & 1965 & 1969 & 1973 & 1977 & 1981 & 1985 & 1989 & 1993 & 1997 & 2001 & 2005 & 2009\end{array}$

Wind Speed $(K \mathrm{~m} / \mathrm{h})$

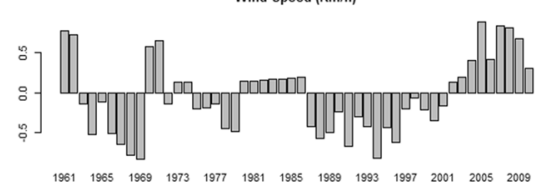

Year

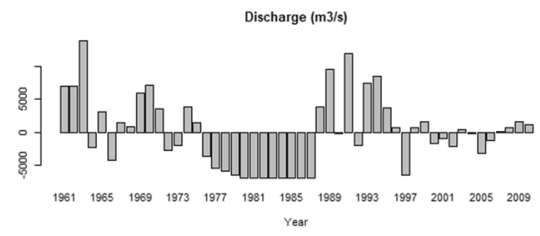

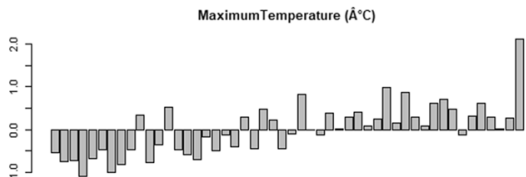

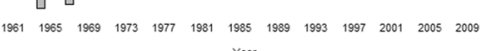

Year

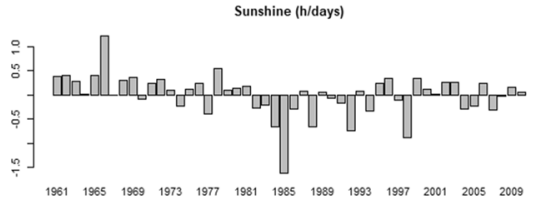

Year

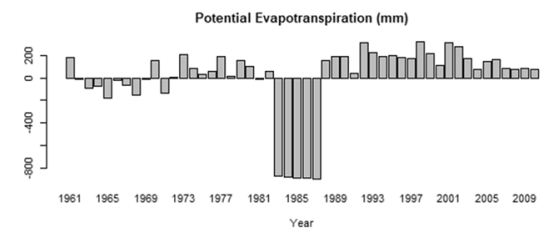

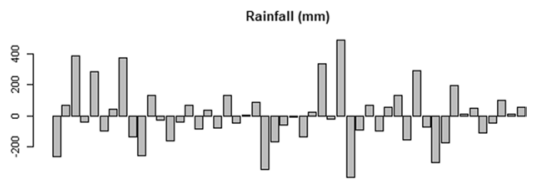

$\begin{array}{lllllllllllll}1961 & 1965 & 1969 & 1973 & 1977 & 1981 & 1985 & 1989 & 1993 & 1997 & 2001 & 2005 & 2009\end{array}$

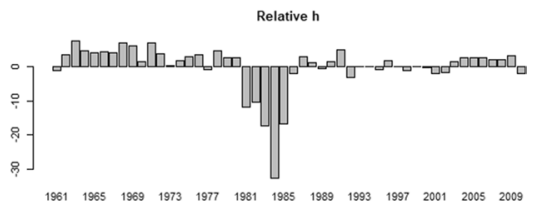

Year

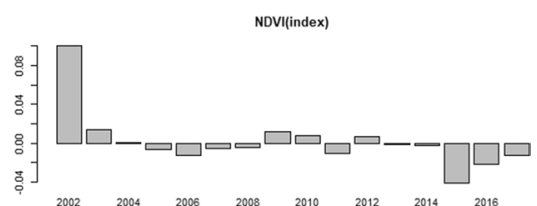

Fig. 3 Inter-annual anomalies of the hydro-climatic and NDVI variables: total discharge $\left(\mathrm{m}^{3} / \mathrm{s}\right)$; sunshine (h/days); maximum temperature $\left({ }^{\circ} \mathrm{C}\right)$; wind speed $(\mathrm{Km} / \mathrm{h})$; relative humidity $(\%)$; mean minimum temperature $\left({ }^{\circ} \mathrm{C}\right)$; rainfall $(\mathrm{mm})$; PET, potential evapotranspiration (mm); and NDVI, normalized difference vegetation index) (Authors' design, 2020) 


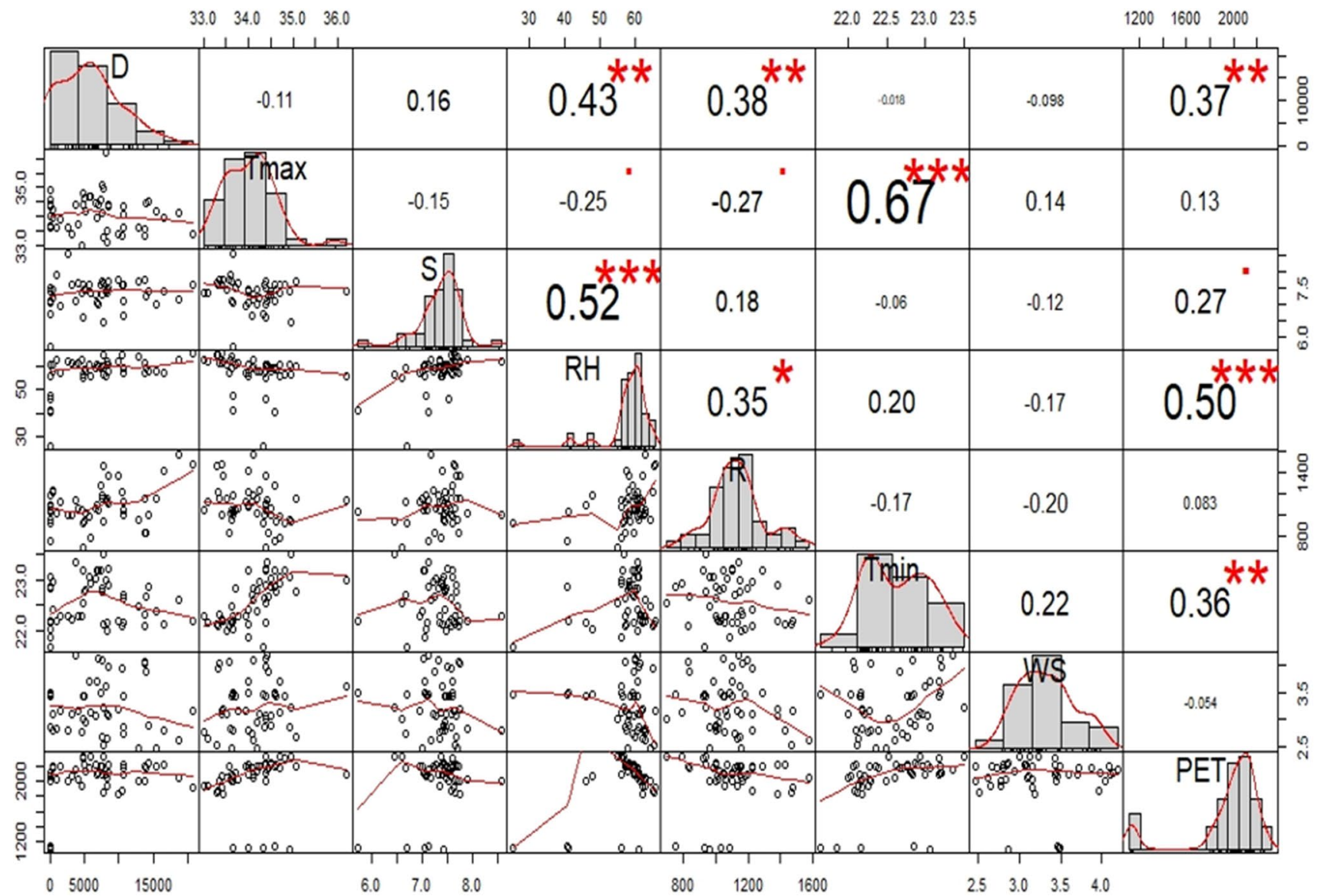

Fig. 4 Correlation values of the hydro-climatic variables in the catchment shown on the top of the diagonal with the significance level as stars $(* * *, * *$ and $*$ represent for $p<<0.001, p=0.001$ to 0.01 , $p=0.01$ to 0.05 ). The distribution of each variable is shown on the diagonal. On the bottom of the diagonal: the bivariate scatter plots with a fitted line are displayed (Authors' design, 2020) has an insignificant negative relationship with wind speed. When both minimum and maximum temperature increase, discharge, duration of sunshine, relative humidity and rainfall insignificantly decrease, meanwhile wind speed increased but insignificantly. Both maximum and minimum temperatures have a significantly positive relationship.

\subsection{Land use/cover changes over the last 3 decades}

The landscape dynamics over 30 years in the Nasia catchment was assessed from 2000 to 2020 at decadal intervals (interval 1 (2000-2010) and interval 2 (2010-2020)) (Fig. 5). Table 4 presents the land use/cover class sizes in percentage and their changes during the two intervals.
The total land area of the Nasia catchment is 534,252 hectares. From 2000 to 2010, water bodies decreased by $0.34 \%$ and increased by $0.10 \%$ from 2010 to 2020 . Forest coverage also decreased by $9.69 \%$ during the first interval and increased by $4.23 \%$ in the second interval.

Grassland and shrubland increased by about $5.05 \%$ and $10.46 \%$, respectively, in the first interval. During the second interval, grassland decreased at $14.76 \%$, while shrubland again increased by $7.17 \%$. Settlement/bare areas increased in both intervals with a higher increase from 2010 to 2020 (3.04\%). Cropland decreased by $5.55 \%$ in the first interval and marginally increased $(0.22 \%)$ in the second interval. Over the entire 30-year period, shrubland and settlement/ bare lands have increased by $17.62 \%$ and $3.1 \%$, respectively, 
Fig. 5 Land use/cover changes in Nasia catchment for the years 2000, 2010 and 2020 (Authors' design, 2020)

Table 4 Land use/cover classes in the Nasia Basin (\%)

Fig. 6 Changes in land use/ cover over the entire 20-year period expressed in percentages (Authors' design, 2020)
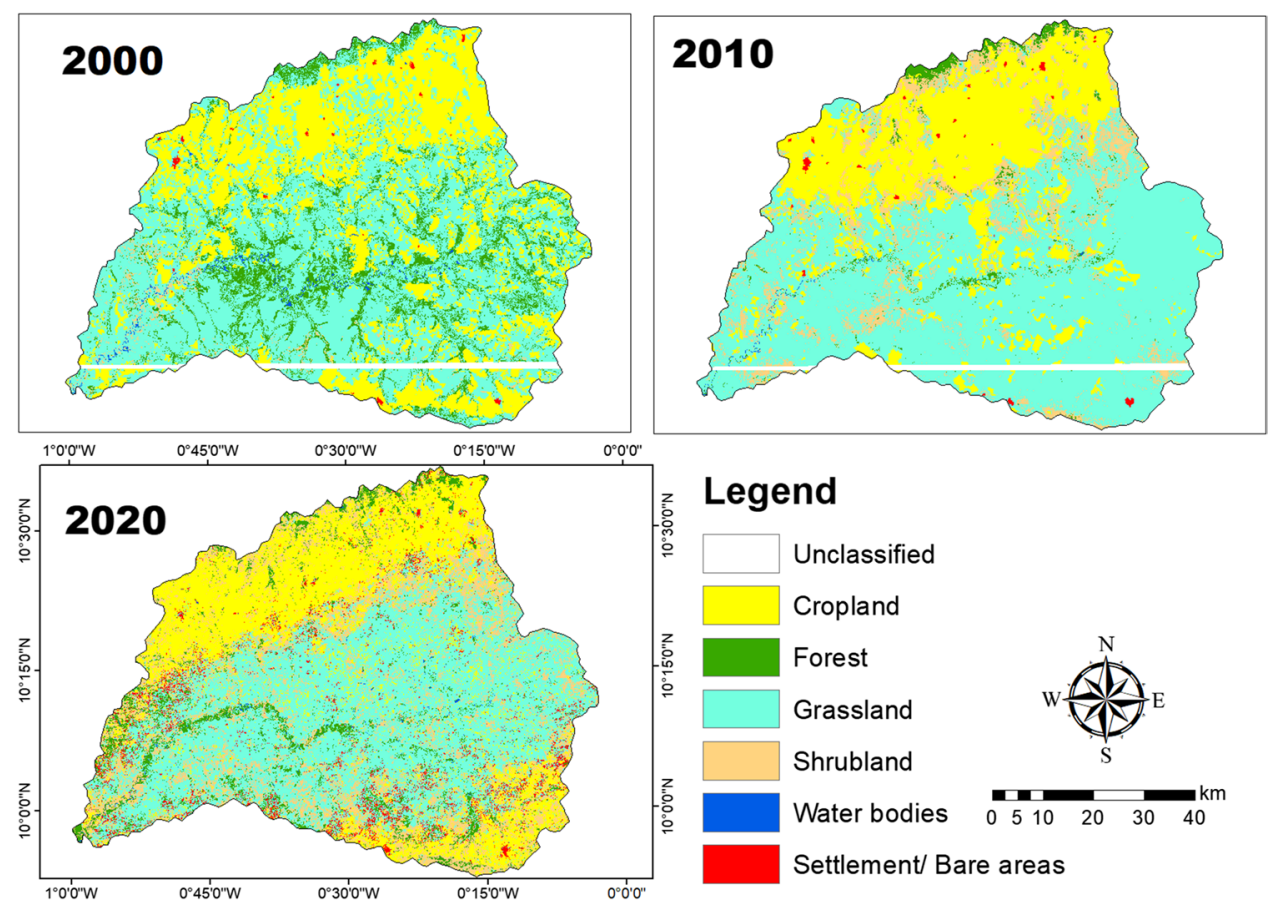

\begin{tabular}{lllllc}
\hline LULC & Year 2000 & Year 2010 & Year 2020 & $\begin{array}{l}\text { Interval 1 } \\
(2010-2000)\end{array}$ & $\begin{array}{c}\text { Interval 2 } \\
(2020-2010)\end{array}$ \\
\hline Cropland & 32.72 & 27.17 & 27.40 & -5.55 & 0.22 \\
Forest & 11.61 & 1.92 & 6.15 & -9.69 & 4.23 \\
Grassland & 53.70 & 58.75 & 43.99 & 5.05 & -14.76 \\
Shrubland & 1.33 & 11.79 & 18.96 & 10.46 & 7.17 \\
Water bodies & 0.42 & 0.09 & 0.19 & -0.34 & 0.1 \\
Settlement/bare areas & 0.22 & 0.28 & 3.32 & 0.07 & 3.04 \\
Total & 100 & 100 & 100 & & \\
\hline
\end{tabular}

(Authors' computations, 2020).

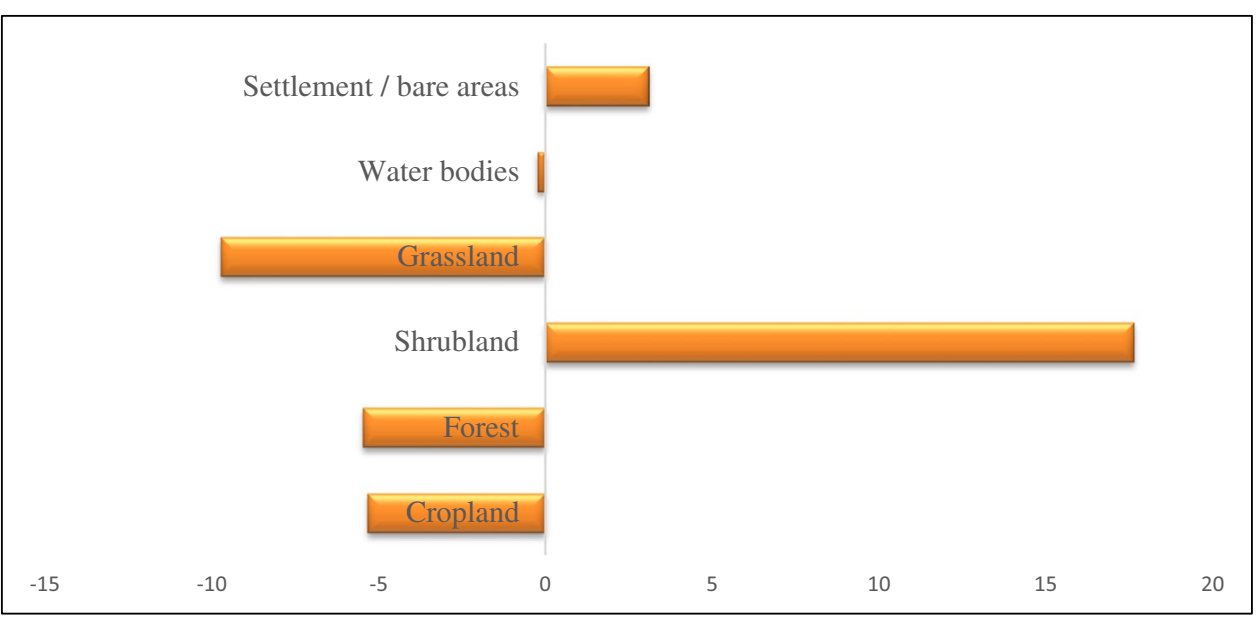


while all other land covers have decreased $(5.32 \%$ cropland, $5.46 \%$ forest, $9.71 \%$ grassland and $0.24 \%$ water bodies) (Fig. 6).

\section{Discussion}

This paper sets out to understand the trends and relationship between the hydro-climatic variables and land use/ cover changes in the Nasia catchment. Here, we discussed the implications of the results, and their impacts on agriculture and the livelihood of the people in the catchment are discussed.

\subsection{Trends and implications of hydro-climatic factors in Nasia}

\subsubsection{Maximum and minimum temperature and rainfall}

The occurrence of a significant increasing trend in both maximum and minimum temperature over the study area highlights the existence of a warming climate in the Nasia catchment in the Northern region of Ghana. Rainfall within the basin shows a decreasing but insignificant trend. Similar trends of temperature and rainfall have been discussed in studies performed in Northern Ghana, where Nasia catchment is located (Amikuzino and Donkoh 2012; Frimpong et al. 2014; Issahaku et al. 2016; Nyadzi 2016; Awuni et al. 2018). Rainfall variability over West Africa is naturally high, with studies showing rainfall shortage of about $10-15 \%$ during the 1980 s, relative to the 1950 s (Mahe 2006). At the same time, temperature increased over Africa, with significant changes since the late 1970s (Hulme et al. 2001). The negative impact of increasing temperatures (minimum and maximum) and decreasing rainfall has implications for soil and water management and agriculture productivity in general. An increase in temperature coupled with warm nights and reduced rainfall will in particular affect crops and weed growth and also increase the prevalence of insects, pests and diseases (Hatfield et al. 2011).

\subsubsection{Sunshine hours}

The duration of sunshine (hours) within the basin has significantly declined, perhaps due to increasing atmospheric aerosols and other air pollutants (Stanhill and Cohen 2001), and increased cloudiness (Cutforth and
Judiesch (2007). Sunshine duration remains an important climatic factor driving crop productivity especially because it drives photosynthesis which greatly influences plant growth (Wu et al. 2006; Alemu and Henebry 2017). Agronomic studies have shown that sunshine plays a critical role in crop water demand (Baskerville and Emin 1969; Ritchie and Nesmith 1991). In a study conducted by Guo et al. (2020), the authors found that the impact of sunshine duration on agricultural water use is statistically significant and that a $1 \%$ increment of sunshine duration hours will partially lead to a $0.145 \%$ decrement in agricultural water use. Stanhill and Cohen (2001) also report that a decrease in solar radiation would impact crop water balance and evapotranspiration of crops with a limiting effect on crop productivity.

\subsubsection{Potential evapotranspiration}

The findings show that potential evapotranspiration in the Nasia basin has significantly increased over the last 50 years. This implies that open water evaporation, bare soil evaporation, rainfall interception evaporation and vegetation transpiration could also be increasing within the basin (Zeng et al. 2018; Tadese et al. 2020). Potential evapotranspiration is an important constituent of the energy and hydrological cycles at the land surface and a vital regulating factor for agricultural water management and calculating crop water requirements (Pengli et al. 2006; Paparrizos et al. 2017; Han et al. 2018). Apart from sunshine duration as mentioned earlier, the significantly increasing wind speed and temperatures and decreasing in relative humidity at a significant rate might have contributed to the rapid increase in potential evapotranspiration which could impact ecological changes, the hydrological cycle and agriculture irrigation management in the basin (King et al. 2015; Ning et al. 2016).

\subsubsection{Wind speed and relative humidity}

The increase in wind speed and decrease in relative humidity will not only affect agriculture in the basin but also have harmful impacts on the health of the inhabitants (Csavina et al., 2014), and when breathed, this can have negative impacts on the human respiratory and cardiovascular systems, due to the spores and contaminants associated with dust and aerosols (Ghio and Devlin 2001; Low et al. 2006; Quintero et al. 2010; Csavina et al. 2011; Degobbi et al. 2011). The 
combination of wind speed and relative humidity could increase the presence of dust and aerosols in the basin. Wind speed remains the primary factor in dust generation with soil structure and vegetation cover also playing significant roles (Zobeck and Fryrear 1986; Zobeck 1991; Yin et al. 2007). Also, the threshold velocity for aeolian erosion is dependent on relative humidity due to its impact on soil surface moisture content which, in turn, affects interparticle cohesion (Ravi and D'Odorico 2005; Ravi et al. 2006; Neuman and Sanderson 2008). Already, the North of Ghana is known to be very dusty, as a result of local and regional aeolian erosion due to the nature of the soil materials dominated by the clay mineral kaolinite (Tiessen et al. 1991; He et al. 2007). The concentration of dust and aerosols in the air gets worst during the harmattan where the dry dust-laden continental wind from the Bodélé Depression in the Chad basin blows over the West African countries along the Gulf of Guinea (Sunnu et al. 2008; Lyngsie et al. 2011).

\subsubsection{River discharge}

The insignificant decrease in annual discharge of the Nasia River with the corresponding insignificant decrease in rainfall and significant rising temperatures and evapotranspiration is indicating water scarcity and possibilities of droughts in the basin (Sheffield and Wood 2008; Dai 2011; Seneviratne 2012). Some studies have shown that for almost all the rivers of West Africa, discharge has decreased after 1970. Yet the changes in the rainfall and discharge relationships are not proportional, presenting a paradoxical situation (Mahé et al. 2000; Mahe 2006). The decreasing trend in the discharge of the Nasia River is bad news for inhabitants of the basin who depend on its water for both agriculture (irrigation) and domestic use. The water crisis in the basin will significantly impact the livelihood of people as rainfed agriculture remains the main economic activity challenged by a long period of dry season. Abdul-Ganiyu et al. (2011) however mention that the flow of the Nasia River may not be attributed to climatic factors alone but also influenced by the physical characteristics (such as topography, soil and vegetation) as well as human activities in the catchment. Adeyeri et al. (2020) however reported that the contribution of human activity to annual discharge variation can be remarkably larger than the contribution of rainfall variability in several regions of the world.

\subsection{Hydro-climatic jumps and implication for agriculture in Nasia}

Following the beginning of $\mathrm{R}$ reduction in 1968 and subsequently discharge in 1975, a significant breakpoint of Tmin, Tmax, S, RH and PET occurred within the 1980s a period that coincides with the occurrence of unprecedented drought events in the history of Ghana (Tan and Rockmore 2019). The drought of 1968-1983 in West Africa, which started imperceptibly in the 1960s in the Sahel-SaharaSudano-Guinea region, affected all meteorological stations in Ghana. The North of Ghana particularly recorded a long and pronounced drought years resulting in the destruction of farms, livestock and other forms of life and property by bush fires (Tandoh, 1985). Since the analysis reveals a breaking point and trends that coincide with past events, the reduction in $\mathrm{R}$ and $\mathrm{D}$, in particular, has significant implications for agriculture in the area. Water availability is becoming a limiting factor for crop production. Planting drought-resistant crop varieties with low water requirements in addition to sustainable water management practices is a possible way to increase yields. Moreover, agriculture in the Nasia catchment is generally hindered by low soil quality which has limited the production of crops to mainly maize, sorghum and millet, which require relatively high levels of water during their growth periods (Antwi-Agyei et al. 2012).

\subsection{Trend and implication of land use/cover change in Nasia}

Over the last three decades, land use/cover are changing in the Nasia catchment; shrubland and settlement/bare lands have increased, while cropland, forest, grassland and water bodies have decreased. The land use/cover changes can allude to the changing hydro-climatic pattern, population growth and economic activities in the basin (Akpoti et al. 2016; Awotwi et al. 2018). The relationship between land use/cover changes and river discharge depends on the basin's size and location, elevation, land management and LULC types ( $\mathrm{Li}$ et al. 2001). While this study could not establish the relationship between hydro-climatic variables and land use/cover changes, NDVI observed a similar declining trend as rainfall, river discharge, potential evapotranspiration, relative humidity and sunshine duration. Similarly, forests, water bodies, cropland and grassland also declined. Hao et al. (2004) concluded that a positive correlation exists between river discharge and forest cover over the Naoli Basin of China. 
It is, therefore, speculated that the trend in hydro-climatic conditions of Nasia catchment in addition to human activities such as settlement development, agriculture and deforestation plays a critical role in the land use/cover pattern of the area.

Human impact on the environment is increasing the speed of land cover changes in the area. Generally, in Africa, people practice deforestation to increase croplands (Mahe 2006). Yet in this study, deforestation resulted in increased settlement and shrubland coverage, compared to croplands, signalling a reduction in farming activities in the basin. Excessive use of trees for charcoal and wood fires and uncontrolled bushfires are the main drivers of deforestation in sub-Saharan Africa (Obahoundje et al., 2018). Firewood or wood fuel accounts for $70 \%$ of sub-Saharan Africa total energy production, and due to the increase in population growth rate, and relative price changes of alternate energy sources for cooking, it is expected that the trend of using firewood will continue (Kebede et al., 2010).

\subsection{Limitations and relevance of the study}

Climate variability could be a natural expression of atmospheric dynamics, yet temporary discontinuities in the data produced by non-climatic factors such as location of weather station, changes observation routine, recalibration or degradation of sensors are also possible (Wijngaard et al., 2003). It is recognized that the major setback of the study is the inability to use robust methods to determine the impact of the changing hydro-climatic factors and land use/cover changes on agriculture and livelihood as a whole. However, the speculations made in the discussions are based on relevant existing literature. Also, another weakness of the study was that the hydro-climatic data used may not reflect the current trend of events as they ranged from 1961 to 2010. However, the lack of data did not adversely affect the results obtained from this study. Therefore, further study to examine the current and future trends as well as to establish the impact on agriculture and livelihood using impact models is recommended. Assessing the long-term behaviour and relationship and detecting breakpoints of hydro-climatic factors and land use/ cover are important, not only to increase knowledge about climate variability but also to develop strategies and implement more adequate water management policies at regional and local scales for the planning of sustainable agricultural practices (de Carvalho et al. 2014; Huntington 2010).

\section{Conclusion and recommendations}

This study examined the trends of hydro-climatic variables (minimum and maximum temperature, wind speed, sunshine duration, rainfall, relative humidity, discharge and potential evapotranspiration), NDVI and land use cover/change in the Nasia catchment. The relationship between these parameters was also analysed in addition to the possible implications of the observable changes in the Nasia catchment.

Generally, the results presented signal water scarcity and possibilities of droughts in the Nasia catchment. The impact of climate change on the overall hydro-climatic variables is quite noticeable. At a $95 \%$ confidence level, minimum and maximum temperatures, wind speed and potential evapotranspiration showed a significant upward trend. Relative humidity and sunshine duration showed a significant downward trend. Rainfall, river discharge and NDVI also showed a downward but insignificant trend. Almost all the trends in hydro-climatic variables started in the 1980s, except wind speed in 2001, rainfall in 1968 and discharge in 1975. Discharge showed a positive significant correlation with relative humidity, rainfall and potential evapotranspiration, but an insignificant positive relationship with sunshine duration. The discharge also showed a negative insignificant correlation with temperature (minimum and maximum) and wind speed. Finally, over the entire 30-year period, shrubland and settlement/bare have increased to the disadvantage of cropland, forest, grassland and water bodies.

The limitation of this paper resides in the fact that the combined effect of the understudied variables on water resources, agriculture and livelihood of the inhabitants was speculated, based on literature. Also, the lack of data could not allow current analysis. However, the findings of this paper could help researchers understand the annual variability of hydro-climatic variables and land use/cover changes in the Nasia catchment and therefore become a foundation for further studies. There is a need for additional research to incorporate hydro-climatic variables, land use/cover and human activities into empirical models to identify specific cause and effect relationships, particularly on river discharge. Once these relationships are determined, impact models could be used to simulate and predict the effect of climate change on the water resources, agriculture and livelihood in the Nasia catchment. 


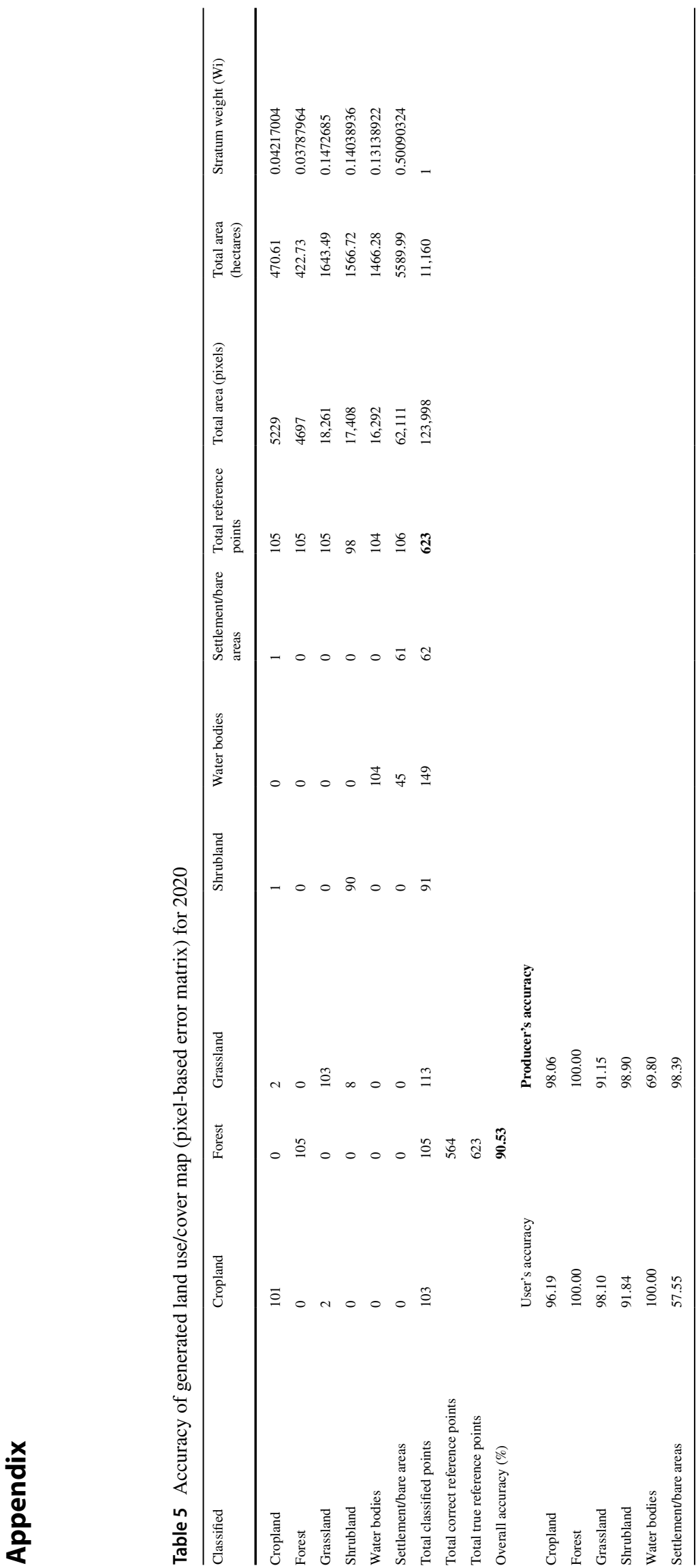




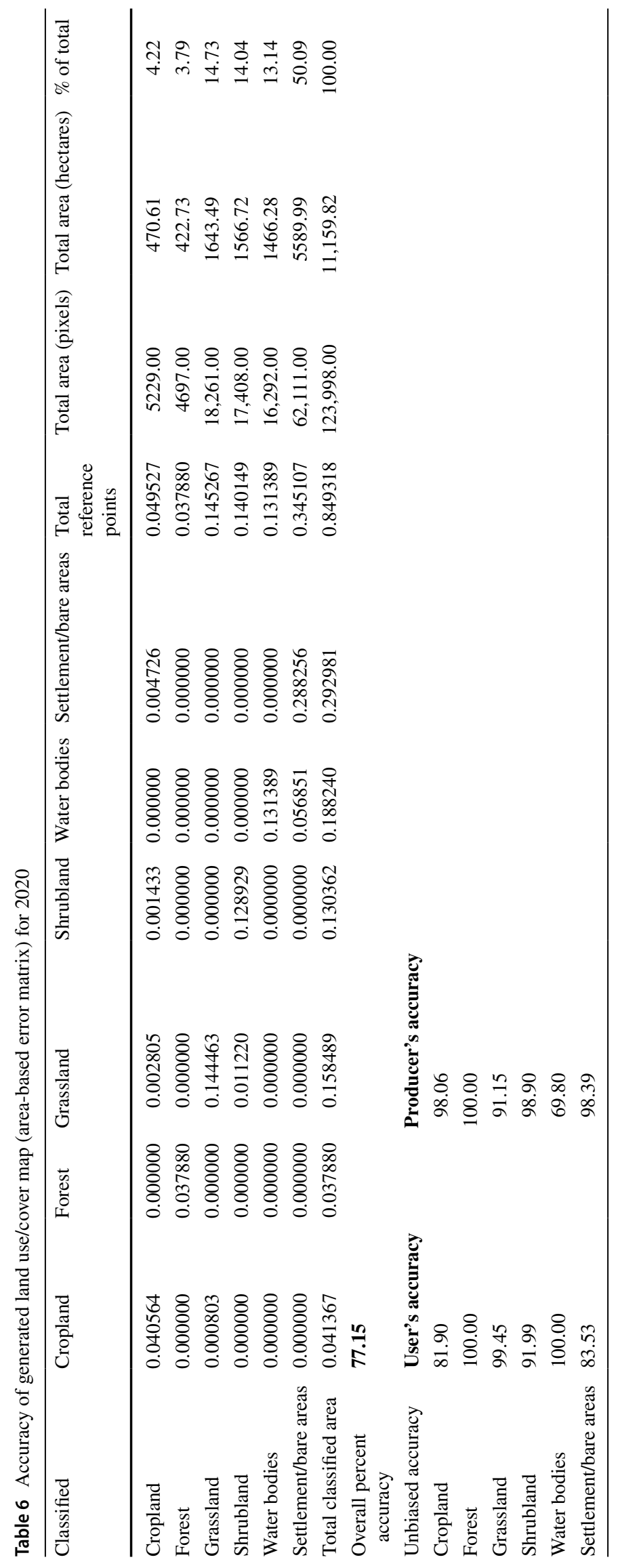


Acknowledgements The authors expressed their profound gratitude to the Ghana Hydrological Services Department (HSD) and the Ghana Meteorological Agency (GMET) for the data used for the study. We also acknowledge the MODIS mission scientists and associated NASA personnel for the production of the NDVI data from Giovanni used in this research effort. We especially thank GlobeLand30 for making 2000 and 2010 land cover maps available for free for this work. Sincere gratitude goes to the European Space Agency (ESA), Geological Survey Department of Ghana and Google Earth developers for access to land use/cover reference data.

Author contribution The study was conceptualized by Emmanuel Nyadzi. The data analysis and writing first draft were done by Emanuel Nyadzi and Enoch Bessah. Supervision, review and writing were performed by Gordana Kranjac-Berisavljevic and Fulco Ludwig.

Data availability The NDVI data that is utilized in this study are openly available in the repository: https://giovanni.gsfc.nasa.gov/giovanni/. The LULC maps of 2000 and 2010 are available at http://www.globa llandcover.com/. The images for the 2020 LULC map are also available at https://glovis.usgs.gov/. The data on hydro-climatic variables are available upon request.

Code availability The codes to generate figures and analyse data in this study are available upon request.

\section{Declarations}

Ethics approval Not applicable.

Consent to participate Not applicable.

Consent for publication All the authors consented to publish the paper.

Conflict of interest The authors declare no competing interests.

Open Access This article is licensed under a Creative Commons Attribution 4.0 International License, which permits use, sharing, adaptation, distribution and reproduction in any medium or format, as long as you give appropriate credit to the original author(s) and the source, provide a link to the Creative Commons licence, and indicate if changes were made. The images or other third party material in this article are included in the article's Creative Commons licence, unless indicated otherwise in a credit line to the material. If material is not included in the article's Creative Commons licence and your intended use is not permitted by statutory regulation or exceeds the permitted use, you will need to obtain permission directly from the copyright holder. To view a copy of this licence, visit http://creativecommons.org/licenses/by/4.0/.

\section{References}

Abdul-Ganiyu S, Kyei-Baffour N, Gbedzi VD (2011) Analysis of some hydrological parameters of the Nasia river catchment in the Northern Region of Ghana for its socio-economic development. Afr J Agric Res 6(24):5533-5540

Addai MO, Yidana SM, Chegbeleh LP, Adomako D, Banoeng-Yakubo B (2016) Groundwater recharge processes in the Nasia sub-catchment of the White Volta basin: analysis of porewater characteristics in the unsaturated zone. J Afr Earth Sc 122:4-14

Adeyeri OE, Laux P, Lawin AE, Arnault J (2020) Assessing the impact of human activities and rainfall variability on the river discharge of Komadugu-Yobe Basin. Lake Chad Area Environmental Earth Sciences 79(6): 1-12

Adu S. V. (1995). Soils of the Nasia river basin Northern Region of Ghana. Soil Research Institute (Council for Scientific and Industrial Research), Academy Post Office, Kwadaso-Kumasi, Ghana.

Aduah MS, Jewitt GP, Toucher ML (2018) Assessing impacts of land use changes on the hydrology of a lowland rainforest catchment in Ghana. West Africa Water 10(1):9

Akpoti K, Antwi EO, Kabo-bah AT (2016) Impacts of rainfall variability, land use and land cover change on stream flow of the black Volta basin. West Africa Hydrology 3(3):26

Alemu WG, Henebry GM (2017) Land surface phenology and seasonality using cool earthlight in croplands of eastern Africa and the linkages to crop production. Remote Sensing 9(9):914

Amikuzino J, Donkoh SA (2012) Climate variability and yields of major staple food crops in Northern Ghana. Afr Crop Sci J 20:349-360

Amisigo BA (2006) Modelling riverflow in the Volta basin of West Africa: a data-driven framework. Cuvillier Verlag. http://resol ver.tudelft.nl/uuid:dcda25cb-d872-4e6d-bca2-1bb0401c8d78. Accessed 14 Nov 2020

Antwi-Agyei P, Fraser ED, Dougill AJ, Stringer LC, Simelton E (2012) Mapping the vulnerability of crop production to drought in Ghana using rainfall, yield and socioeconomic data. Appl Geogr 32(2):324-334

Arnell NW (2004) Climate change and global water resources: SRES emissions and socio-economic scenarios. Glob Environ Chang $14(1): 31-52$

Asfaw A, Simane B, Hassen A, Bantider A (2018) Variability and time series trend analysis of rainfall and temperature in northcentral Ethiopia: a case study in Woleka sub-basin. Weather and Climate Extremes 19:29-41

Awotwi A, Anornu GK, Quaye-Ballard JA, Annor T (2018) Monitoring land use and land cover changes due to extensive gold mining, urban expansion, and agriculture in the Pra River Basin of Ghana, 1986-2025. Land Degrad Dev 29(10):3331-3343

Awuni JA, Azumah SB, Donkoh SA (2018) Drivers of adoption intensity of improved agricultural technologies among rice farmers: evidence from northern Ghana. Rev Agric Appl Econ (RAAE), 21(1340-2018-5180), pp.48-57

Baarsch F, Granadillos JR, Hare W, Knaus M, Krapp M, Schaeffer M, Lotze-Campen H (2020) The impact of climate change on incomes and convergence in Africa. World Development, 126, p.104699

Baskerville GL, Emin P (1969) Rapid estimation of heat accumulation from maximum and minimum temperatures. Ecology 50(3):514-517

Buma WG, Lee SI, Seo JY (2016) Hydrological evaluation of Lake Chad basin using space borne and hydrological model observations. Water 8(5):205

Chaouche K, Neppel L, Dieulin C, Pujol N, Ladouche B, Martin E, Salas D, Caballero Y (2010) Analyses of precipitation, temperature and evapotranspiration in a French Mediterranean region in the context of climate change. CR Geosci 342(3):234-243

Chen J, Chen J, Liao A, Cao X, Chen L, Chen X, ..., Mills J (2015) Global land cover mapping at $30 \mathrm{~m}$ resolution: a POK-based operational approach. ISPRS J Photogrammetry Remote Sens $1037-27$

Codjoe SNA, Atiglo DY (2020) The implications of extreme weather events for attaining the sustainable development goals in subSaharan Africa. Frontiers in Climate 2:18

Csavina J, Landázuri A, Wonaschütz A, Rine K, Rheinheimer P, Barbaris B, Conant W, Sáez AE, Betterton EA (2011) Metal and metalloid contaminants in atmospheric aerosols from mining operations. Water Air Soil Pollut 221(1):145-157 
Csavina J, Field J, Félix O, Corral-Avitia AY, Sáez AE, Betterton EA (2014) Effect of wind speed and relative humidity on atmospheric dust concentrations in semi-arid climates. Sci Total Environ 487:82-90

Cutforth HW, Judiesch D (2007) Long-term changes to incoming solar energy on the Canadian Prairie. Agric for Meteorol 145(3-4):167-175

Dai A (2011) Drought under global warming: a review. Wiley Interdisciplinary Reviews: Climate Change 2(1):45-65

de Carvalho JRP, Assad ED, de Oliveira AF, Pinto HS (2014) Annual maximum daily rainfall trends in the Midwest, southeast and southern Brazil in the last 71 years. Weather and Climate Extremes 5:7-15

de Hipt FO, Diekkrueger B, Steup G, Yira Y, Hoffmann T, Rode M (2018) Modeling the impact of climate change on water resources and soil erosion in a tropical catchment in Burkina Faso, West Africa. CATENA 163:63-77

Degobbi C, Lopes FD, Carvalho-Oliveira R, Muñoz JE, Saldiva PH (2011) Correlation of fungi and endotoxin with PM2. 5 and meteorological parameters in atmosphere of Sao Paulo, Brazil. Atmos Environ 45(13)2277-2283

Elikplim NY, Mustapha O, Zahra LF Laila J (2018) Diaphragmatic hernia following a liver resection: a rare cause of bowel obstruction. Int J Case Rep Images 9 100915Z01NE2018

Forkel M, Carvalhais N, Verbesselt J, Mahecha MD, Neigh CS, Reichstein M (2013) Trend change detection in NDVI time series: effects of inter-annual variability and methodology. Remote Sensing 5(5):2113-2144

Forkuo EK, Frimpong A (2012) Analysis of forest cover change detection. International Journal of Remote Sensing Applications 2(4):82-92

Frédérique M, Agnès B, Louise L, Clovis G (2019) Sensitivity analysis of land productivity change calculation in Mozambique. In IGARSS 2019-2019 IEEE International Geoscience and Remote Sensing Symposium (pp. 1633-1636). IEEE

Frimpong K, Oosthuizen J, Van Etten EJ (2014) Recent trends in temperature and relative humidity in Bawku East, Northern Ghana. Journal of Geography and Geology 6(2):69-81

Ghio AJ, Devlin RB (2001) Inflammatory lung injury after bronchial instillation of air pollution particles. Am J Respir Crit Care Med 164(4):704-708

Gichenje H, Godinho S (2018) Establishing a land degradation neutrality national baseline through trend analysis of GIMMS NDVI time-series. Land Degrad Dev 29(9):2985-2997

Gocic M, Trajkovic S (2013) Analysis of changes in meteorological variables using Mann-Kendall and Sen's slope estimator statistical tests in Serbia. Global Planet Change 100:172-182

Guo C, Dai H, Liu X, Wu Y, Liu X, Liu Y (2020) Impacts of climate change mitigation on agriculture water use: a provincial analysis in China. Geography and Sustainability 1(3):189-199

Han M, Zhang H, DeJonge KC, Comas LH, Gleason S (2018) Comparison of three crop water stress index models with sap flow measurements in maize. Agric Water Manage 203:366-375

Hao FH, Chen LQ, Liu CM, Dai D (2004) Impact of land use change on runoff and sediment yield. J Soil Water Conserv 18(3):5-8

Hatfield JL, Boote KJ, Kimball BA, Ziska LH, Izaurralde RC, Ort D, Thomson AM, Wolfe D (2011) Climate impacts on agriculture: implications for crop production. Agron J 103(2):351-370

He C, Breuning-Madsen H, Awadzi TW (2007) Mineralogy of dust deposited during the Harmattan season in Ghana. Geografisk Tidsskrift-Danish Journal of Geography 107(1):9-15

Hirsch RM, Slack JR, Smith RA (1982) Techniques of trend analysis for monthly water quality data. Water Resour Res 18(1):107-121.

Hulme M, Doherty R, Ngara T, New M, Lister D (2001) African climate change: 1900-2100. Climate Res 17(2):145-168

Huntington TG (2010) Climate warming-induced intensification of the hydrologic cycle: an assessment of the published record and potential impacts on agriculture. Adv Agron 109:1-53
IPCC (2014) Climate change (2013): the physical science basis: contribution of working group I to the fifth assessment report of the intergovernmental panel on climate change. Cambridge University Press, Cambridge

Issahaku AR, Campion BB, Edziyie R (2016) Rainfall and temperature changes and variability in the Upper East Region of Ghana. Earth and Space Science 3(8):284-294

Jasinski MF (1990) — Sensitivity of the normalized difference vegetation index to subpixel canopy cover, soil albedo, and pixel scale.|| Remote Sensing of Environment, 32, 169- 187

Jun C, Ban Y, Li S (2014) Open access to Earth land-cover map. Nature 514(7523):434-434

Kambombe, O.C., (2018). Impact of climate variability and land use change on stream flow in Lake Chilwa basin, Malawi (Doctoral dissertation, Egerton University).

Kankam-Yeboah K, Amevenku FKY, Opoku-Ankomah Y, Bekoe EO (2011) Water users' associations and integrated water resources management in Ghana. Ghana Journal of Science 51:11-23

Kankam-Yeboah K, Obuobie E, Amisigo B, Opoku-Ankomah Y (2013) Impact of climate change on streamflow in selected river basins in Ghana. Hydrol Sci J 58(4):773-788

Kebede E, Kagochi J, Jolly CM (2010) Energy consumption and economic development in Sub-Sahara Africa. Energy Economics 32(3):532-537

Khaliq MN, Ouarda TB, Gachon P, Sushama L, St-Hilaire A (2009) Identification of hydrological trends in the presence of serial and cross correlations: a review of selected methods and their application to annual flow regimes of Canadian rivers. J Hydrol 368(1-4):117-130

King DA, Bachelet DM, Symstad AJ, Ferschweiler K, Hobbins M (2015) Estimation of potential evapotranspiration from extraterrestrial radiation, air temperature and humidity to assess future climate change effects on the vegetation of the Northern Great Plains, USA. Ecol Model 297:86-97

Kranjac-Berisavljevic G (1999) Recent climatic trends in northern interior savannah zone of Ghana; implication for agricultural production. Conference paper: Integrated Drought Management, 20-22 September 1999, Pretoria South Africa

Lal R, Singh BR, Mwaseba DL, Kraybill D, Hansen DO, Eik LO (eds) (2015) Sustainable intensification to advance food security and enhance climate resilience in Africa. Springer International Publishing, Switzerland

Li X, Peterson J, Liu GJ, Qian L (2001) Assessing regional sustainability: the case of land use and land cover change in the middle Yiluo catchment of the Yellow River basin. China Applied Geography 21(1):87-106

Lillesand TM, Kiefer RW, Chipman JW (2004) Remote sensing and image interpretation. $\|$, th edn. John Wiley \& Sons Inc., New York

Long M, Entekhabi D, Nicholson SE (2000) Interannual variability in rainfall, water vapor flux, and vertical motion over West Africa. J Clim 13(21):3827-3841

Los SO, Weedon GP, North PRJ, Kaduk JD, Taylor CM, Cox PM (2006) An observation-based estimate of the strength of rainfall-vegetation interactions in the Sahel. Geophysical Research Letters, 33(16)

Low RB, Bielory L, Qureshi AI, Dunn V, Stuhlmiller DF, Dickey DA (2006) The relation of stroke admissions to recent weather, airborne allergens, air pollution, seasons, upper respiratory infections, and asthma incidence, September 11, (2001), and day of the week. Stroke 37(4):951-957

Lyngsie G, Awadzi T, Breuning-Madsen H (2011) Origin of Harmattan dust settled in Northern Ghana-long transported or local dust? Geoderma 167:351-359

Mahé G, Olivry JC, Dessouassi R, Orange D, Bamba F, Servat E (2000) Surface water and groundwater relationships in a tropical river 
of Mali. Comptes Rendus De L'académie Des Sciences-Series IIA-Earth and Planetary Science 330(10):689-692

Mahe GIL (2006) The impacts of land use/land cover change and climate variability on the hydrology of the Sahel. IAHS Publ 308:679

Mallakpour I, Villarini G (2016) A simulation study to examine the sensitivity of the Pettitt test to detect abrupt changes in mean. Hydrol Sci J 61(2):245-254

Mann, H. B. (1945). Nonparametric tests against trend. Econometrica: J Econ Soc, 245-259

Meneses-Tovar CL (2011) NDVI as indicator of degradation. Unasylva 62(238):39-46

Meshram SG, Kahya E, Meshram C, Ghorbani MA, Ambade B, Mirabbasi R (2020) Long-term temperature trend analysis associated with agriculture crops. Theoret Appl Climatol 140(3):1139-1159

Mikulewicz M, Taylor M (2020) Getting the resilience right: climate change and development policy in the 'African Age'. New Political Economy 25(4):626-641

Moritz S, Bartz-Beielstein T (2017) imputeTS: time series missing value imputation in R. R J 9(1):207

Mwangi HM, Julich S, Patil SD, McDonald MA, Feger KH (2016) Relative contribution of land use change and climate variability on discharge of upper Mara River, Kenya. Journal of Hydrology: Regional Studies 5:244-260

Neuman MC, Sanderson S (2008) Humidity control of particle emissions in aeolian systems. Journal of Geophysical Research: Earth Surface 113(F2)

Nicholson SE, Some B, Kone B (2000) An analysis of recent rainfall conditions in West Africa, including the rainy seasons of the 1997 El Niño and the 1998 La Niña years. J Clim 13(14):2628-2640

Ning T, Li Z, Liu W, Han X (2016) Evolution of potential evapotranspiration in the northern Loess Plateau of China: recent trends and climatic drivers. Int J Climatol 36(12):4019-4028

Nyadzi E (2016) Climate variability since 1970 and farmers' observations in Northern Ghana. Sustainable Agric Res 5(526-2016-37880)

Obahoundje S, Diedhiou A, Ofosu EA, Anquetin S, François B, Adounkpe J, ..., Youan Ta M (2018) Assessment of spatiotemporal changes of land use and land cover over South-Western African basins and their relations with variations of discharges. Hydrology, 5(4), 56

Oguntunde PG, Friesen J, van de Giesen N, Savenije HH (2006) Hydroclimatology of the Volta River Basin in West Africa: trends and variability from 1901 to 2002 . Physics and Chemistry of the Earth, Parts a/b/c 31(18):1180-1188

Olofsson P, Foody GM, Stehman SV, Woodcock CE (2013) Making better use of accuracy data in land change studies: Estimating accuracy and area and quantifying uncertainty using stratified estimation. Remote Sens Environ 129:122-131

Önöz B, Bayazit M (2012) Block bootstrap for Mann-Kendall trend test of serially dependentdata. Hydrol Process 26(23):3552-3560

Osunmadewa BA, Wessollek C, Karrasch P (2014) October. Identification of long-term trends in vegetation dynamics in the guinea savannah region of Nigeria. In Remote sensing for agriculture, ecosystems, and hydrology XVI (Vol. 9239, p. 92390F). International Society for Optics and Photonics

Paeth H, Born K, Girmes R, Podzun R, Jacob D (2009) Regional climate change in tropical and northern Africa due to greenhouse forcing and land use changes. J Clim 22(1):114-132

Paparrizos S, Maris F, Matzarakis A (2017) Sensitivity analysis and comparison of various potential evapotranspiration formulae for selected Greek areas with different climate conditions. Theoret Appl Climatol 128(3-4):745-759

Partal T, Kahya E (2006) Trend analysis in Turkish precipitation data. Hydrological Processes: an International Journal 20(9):2011-2026
Pengli M, Xingguo Y, Duansheng C, Hongyi L, Qiguo Y (2006) Responses of crop water requirements to climatic changes. Acta Botanica Boreali-Occidentalia Sinica 26(2):348-353

Pettitt AN (1979) A non-parametric approach to the change-point problem. J Roy Stat Soc: Ser C (appl Stat) 28(2):126-135

Quintero E, Rivera-Mariani F, Bolaños-Rosero B (2010) Analysis of environmental factors and their effects on fungal spores in the atmosphere of a tropical urban area (San Juan, Puerto Rico). Aerobiologia 26(2):113-124

Ravi S, D'Odorico P (2005) A field-scale analysis of the dependence of wind erosion threshold velocity on air humidity. Geophysical Res Lett 32(21)

Ravi S, Zobeck TM, Over TM, Okin GS, D'Odorico P (2006) On the effect of moisture bonding forces in air-dry soils on threshold friction velocity of wind erosion. Sedimentology 53(3):597-609

Reiter A, Weidinger R, Mauser W (2012) Recent climate change at the upper Danube - a temporal and spatial analysis of temperature and precipitation time series. Clim Change 111(3):665-696

Rezende M, Riccardi T, Malatesta L, Attorre F, Van Damme K (2020) Land productivity dynamics in Socotra Island (Yemen). Rendiconti Lincei Scienze Fisiche e Naturali 31(3):737-746

Ritchie JT, Nesmith DS (1991) Temperature and crop development. Modeling Plant and Soil Systems 31:5-29

Sabbaghi, M.A., Nazari, M., Araghinejad, S. and Soufizadeh, S., (2020). Economic impacts of climate change on water resources and agriculture in Zayandehroud river basin in Iran. Agricultural Water Management, 241, p.106323.

Sader SA, Winne JC (1992) RGB-NDVI colour composites for visualizing forest change dynamics. Int J Remote Sens 13:3055-3067

Sahoo D, Smith PK (2009) Hydroclimatic trend detection in a rapidly urbanizing semi-arid and coastal river basin. J Hydrol 367(3-4):217-227

Schilling J, Hertig E, Tramblay Y, Scheffran J (2020) Climate change vulnerability, water resources and social implications in North Africa. Reg Environ Change 20(1):1-12

Schmidt M, Klein D, Conrad C, Dech S, Paeth H (2014) On the relationship between vegetation and climate in tropical and northern Africa. Theoret Appl Climatol 115(1):341-353

Seneviratne SI (2012) Historical drought trends revisited. Nature 491(7424):338-339

Serdeczny O, Adams S, Baarsch F, Coumou D, Robinson A, Hare W, Schaeffer M, Perrette M, Reinhardt J (2017) Climate change impacts in Sub-Saharan Africa: from physical changes to their social repercussions. Reg Environ Change 17(6):1585-1600

Sesnie SE, Gessler PE, Finegan B (2008) Integrating Landsat TM and SRTM-DEM derived variables with decision trees for habitat classification and change detection in complex neotropical environments.|| Remote Sensing of Environment, 112, 2145-2159

Sheffield J, Wood EF (2008) Projected changes in drought occurrence under future global warming from multi-model, multi-scenario, IPCC AR4 simulations. Clim Dyn 31(1):79-105

Speranza IC (2010) Resilient adaptation to climate change in African agriculture. Studies, No. 54, ISBN 978-3-88985-489-6, Deutsches Institut für Entwicklungspolitik (DIE), Bonn

Stanhill G, Cohen S (2001) Global dimming: a review of the evidence for a widespread and significant reduction in global radiation with discussion of its probable causes and possible agricultural consequences. Agric for Meteorol 107(4):255-278

Sun CC, Shen ZY, Xiong M, Ma FB, Li YY, Chen L, Liu RM (2013) Trend of dissolved inorganic nitrogen at stations downstream from the Three-Gorges Dam of Yangtze River. Environ Pollut 180:13-18

Sunnu A, Afeti G, Resch F (2008) A long-term experimental study of the Saharan dust presence in West Africa. Atmos Res 87(1):13-26 
Tabari H, Talaee PH (2011) Analysis of trends in temperature data in arid and semi-arid regions of Iran. Global Planet Change 79(1-2):1-10

Tadese M, Kumar L, Koech R (2020) Long-term variability in potential evapotranspiration, water availability and drought under climate change scenarios in the Awash River basin. Ethiopia Atmosphere 11(9):883

Tan CM, Rockmore M (2019) Famine in Ghana and its impact. In: Preedy, V. R., \& Patel, V. B. (Eds.). (2019). Handbook of famine, starvation, and nutrient deprivation: from biology to policy. Springer

Tandoh, S E 1985 Climate patterns and changes of the West African climate in report of workshop on combating the effects of drought and desertification. 24-25 January, 1985. Accra, Ghana.

Tehrani EN, Sahour H, Booij MJ (2019) Trend analysis of hydroclimatic variables in the north of Iran. Theoret Appl Climatol 136(1):85-97

Thanh Noi P, Kappas M (2018) Comparison of random forest, k-nearest neighbor, and support vector machine classifiers for land cover classification using Sentinel-2 imagery. Sensors 18(1):18

Tian F, Fensholt R, Verbesselt J, Grogan K, Horion S, Wang Y (2015) Evaluating temporal consistency of long-term global NDVI datasets for trend analysis. Remote Sens Environ 163:326-340

Tiessen H, Hauffe HK, Mermut AR (1991) Deposition of Harmattan dust and its influence on base saturation of soils in northern Ghana. Geoderma 49(3-4):285-299

Unal YS, Deniz A, Toros H, Incecik S (2012) Temporal and spatial patterns of precipitation variability for annual, wet, and dry seasons in Turkey. Int J Climatol 32(3):392-405

Wang G, Eltahir EA (2000) Ecosystem dynamics and the Sahel drought. Geophys Res Lett 27(6):795-798

Warburton ML, Schulze RE, Jewitt GP (2012) Hydrological impacts of land use change in three diverse South African catchments. J Hydrol 414:118-135

Wijngaard JB, Klein Tank AMG, Können GP (2003) Homogeneity of 20th century European daily temperature and precipitation series. International Journal of Climatology: A Journal of the Royal Meteorological Society 23(6):679-692
World Bank (2010) Development and Climate Change: World Development Report 2010

WRCG (Water Resources Commission - Ghana) (2008) White Volta River Basin-Integrated Water Resources Management Plan. WRC, Accra

Wu D, Yu Q, Lu C, Hengsdijk H (2006) Quantifying production potentials of winter wheat in the North China Plain. Eur J Agron 24(3):226-235

Xu Z, Liu Z, Fu G, Chen Y (2010) Trends of major hydroclimatic variables in the Tarim River basin during the past 50 years. J Arid Environ 74(2):256-267

Yin D, Nickovic S, Sprigg WA (2007) The impact of using different land cover data on wind-blown desert dust modeling results in the southwestern United States. Atmos Environ 41(10):2214-2224

Zeng Z, Peng L, Piao S (2018) Response of terrestrial evapotranspiration to Earth's greening. Current Opinion in Environmental Sustainability 33:9-25

Zhang M, Huang X, Chuai X, Yang H, Lai L, Tan J (2015) Impact of land use type conversion on carbon storage in terrestrial ecosystems of China: a spatial-temporal perspective. Sci Rep 5(1):1-13

Zhou J, Liang Z, Liu Y, Guo H, He D, Zhao L (2015a) Six-decade temporal change and seasonal decomposition of climate variables in Lake Dianchi watershed (China): stable trend or abrupt shift? Theoret Appl Climatol 119(1):181-191

Zhou L, Jiang Z, Li Z, Yang X (2015b) Numerical simulation of urbanization climate effects in regions of East China. Chin J Atmos Sci 39(3):596-610

Zobeck TM (1991) Soil properties affecting wind erosion. J Soil Water Conserv 46(2):112-118

Zobeck TM, Fryrear DW (1986) Chemical and physical characteristics of windblown sediment II. Chemical characteristics and total soil and nutrient discharge. Transactions of the ASAE, 29(4):1037-1041

Publisher's note Springer Nature remains neutral with regard to jurisdictional claims in published maps and institutional affiliations. 